\title{
Hyphenating Ireland and America: the contemporary construction of identity, film, and media in a hybrid space
}

\section{Loretta Goff}

School of English-Film Studies, UCC

The spectacle is not a collection of images; it is a social relation between people that is mediated by images. (Guy Debord, The Society of the Spectacle)

\section{Introduction}

In our increasingly globalized world evolving technologies have developed new networks for connection, primarily through the internet. These allow for the instantaneous spread of information, but also provide greater influence to the media and marketed ideas. Along with these developed technologies and networks, so too have the relationships between countries evolved. Ireland and America have long been connected, with millions of Irish emigrating to America through the years, contributing to its development as a nation and producing today's nearly forty million Irish-Americans. But what is the current relationship between the two countries and how connected to Ireland are generations removed IrishAmericans?

My research uses film, at both levels of production and representation, as a case study for the contemporary hyphenation of Ireland and America into a hybrid space largely constructed for profit, and the problematic performance of identity within this space. Film makes a particularly useful case study for this due to its nature as an early and lasting cultural export that is purposefully constructed, its ability to capture performance, and its popularity and influence. Not only do films reflect identity and international relationships, they also link with other media, including the internet, which contribute largely to the current relationship of Ireland and America. As it is this contemporary relationship and identity that I am interested in, my case study particularly looks at a broad base of Irish and 'Irish-themed' films produced from the early 1990s onward. The choice of this particular time-frame is significant as it marks the beginnings of both the Celtic Tiger and the popularization of the internet, both highly influential in developing this relationship to its current state.

\section{The hyphen as a currency symbol}

Hyphenated Americans have long been a topic of debate. On one side the hyphen is looked upon negatively, from Theodore Roosevelt's 1915 speech accusing those who were 
hyphenated as being un-America and John Wayne's song "The Hyphen" which labels it as a "divisive line," to Louisiana Governor Bobby Jindal's recent calls for assimilation and condemnations of those choosing a hyphenated identity. On the other side are those who are proud of their heritage and don't feel it makes them less American to identify with it, such as Irish-American Congressman Joe Crowley who responded to Jindal by suggesting the Governor is suffering an identity crisis. To add to this debate, my argument is that the Irish-American identity has been recognized as a profitable one, and as such has now been developed into a market commodity, effectively replacing the hyphen between the two cultural identities with a currency symbol.

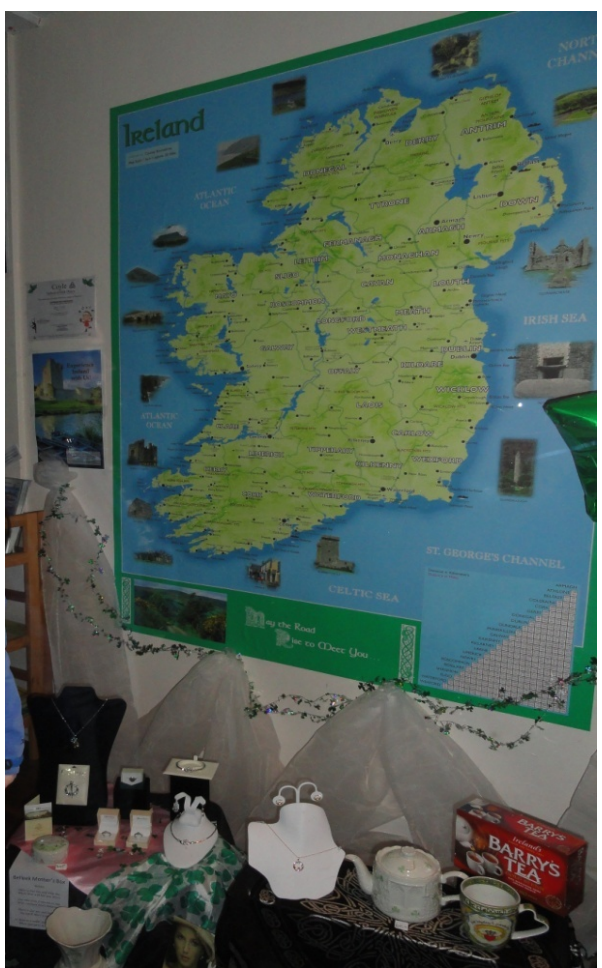

Figure 1: 1. Window display of Irish products for sale in specialty shop in Gettysburg, PA. Source: Loretta Goff

The media has largely shaped what Guy Debord would term a 'spectacle' of the identity, unifying society through commodity. Tourism campaigns such as "The Gathering," along with news stories, the selling of Irish products for the American market, and advertisements all contribute to this. One specific example from this combination of contributors was the presentation of a Certificate of Irish Heritage to actor Tom Cruise as part of "The Gathering" campaign. Though quite a few generations removed from Ireland, Cruise proudly touted his certificate in a number of interviews and it was widely reported by the media. The good news for anyone else wanting to mark their Irish-American identity in this way is that these certificates are available from the Irish Government to anyone of Irish descent for $€ 45$. Though embodying the literal selling of the identity, this does not necessarily make it negative, as it does bring a feeling of connection, belonging, and pride with it. However, it also demonstrates the economic forces-and tourism influences-at 
work in the creation of an Irish-American identity.

\section{Hyphenating Irish film}

Setting clearly defined parameters for an Irish national cinema is a difficult task. Should it include any film with an Irish theme, only those filmed in Ireland, or those done by Irish directors? The fear of Hollywood dominance is not uncommon in national cinemas, and is particularly relevant to Irish cinema, dating back to its early days when Ireland's first film censor, James Montgomery, declared in 1924 that Los Angelesation was a greater danger to Ireland than Anglicization. Therefore, when there is American influence in an Irish film, be it through co-production, the use of stars, or marketing and distribution, this often results in the film being placed in a contested space outside of what is considered 'pure' national cinema, much like a hyphenated identity. The driving force behind this influence is, of course, usually economic in nature and it does impact the films to mixed results. For instance, the casting of Julia Roberts in Michael Collins (1996) was certainly a draw for American audiences and did not change the story or detract from its Irishness. However, her poor Irish accent makes it difficult for Irish audiences to take her character seriously. On the other hand, accent is not a problem if the American star is cast to play the role of an American character in an Irish film. Instead, this use of the star becomes key in driving the narrative as an explanation is needed for why the American is in Ireland. Recent films such as The Guard (2011) and Standby (2014) provide some examples of this. Meanwhile, a number of American films are driven by the fact that they are set in Ireland, with Americans travelling over, which similarly drives the narrative with an Irish theme. The Matchmaker (1997), P.S I Love You (2007), and Leap Year (2010) are among some of the more popular examples of this type of film, though there are quite a few others that follow the style. Ultimately, the linking of Ireland and America at a production level on a film will always filter down to its content in some way, allowing for analysis at a representational level.

\section{Constructing identity and genre}

There are certain key signifiers in the relationship between Ireland and America, and of the Irish-American identity that are built around stereotypes. These include the use of the Irish landscape, alcohol, and religion. When these tropes, along with the interaction of American and Irish characters, are looked at in terms of how they are specifically deployed within genre films in order to meet the conventions of that genre, they actually de-romanticise the Irish American relationship, even from within the 'spectacle.' To use landscape for a brief example, there are a number of romantic comedy films, including Leap Year (2010) wherein a female American travels to Ireland and, while she encounters a beautifully scenic landscape, she is also thrown off balance by this landscape, often falling in the mud and having inappropriate shoes such as heels that break. Meanwhile, in horror 
films such as Shrooms (2007) the landscape is not only visually darker, it also produces hallucinogenic mushrooms that drive the fear in the film and wreak severe havoc with the American female lead's mental state. While the trope of the landscape is employed quite differently in each genre film, the American character is left unsettled because of it in both. By looking at my base of films in terms of how these tropes and identities are constructed within the particular conventions of genre, I am ultimately applying Rick Altman's semantics/syntax approach to film genre to my case study of the Irish-American identity in film. I consider the tropes of the identity as the semantics, or key elements comprising the films, and the conventions of the genre as the syntax, or the specific ways these pieces are arranged and used. Ultimately, though portrayed differently across genres of romantic-comedy, drama, crime and horror, when the Irish-American identity is depicted within and according to the construct of each genre the overall message is that in order to be happy the character must reject one cultural identity for the other. This message illuminates the fact that, overall, films take a conservative approach to the debate over hyphenation, ultimately portraying a singular, 'pure', identity as 'safer', despite profiting off of, and largely encouraging, an Irish American relationship.

\section{Conclusion}

Though genre films may initially appear to be no more than 'spectacle,' taking a deeper look at them reveals the nuances of the contemporary relationship between Ireland and America, and reveals the conservative approach they take in regards to the hyphenated Irish-American identity, calling for cultural assimilation. As Barry Keith Grant points out, "whether they are set in the past or in the future, on the mean streets of a contemporary New York or long ago in a galaxy far away, genre movies are always about the time and place in which they are made." Similarly, whether these films convey what they do because of economic influences and an Irish and American relationship at the production level, or they are just representing the complex contemporary relationship and identity the best way they see fit, these films are key to examining both.

My concentration on the hyphen in the Irish-American identity acts as a magnifying lens for examining the problematic construction of this identity, with ideology and mediation at the core of its formation. The use of film to explore this highlights the fact that identity is a performance, with those seen on screen often being exaggerated displays of daily individual identity performance. In today's digital world where identity performance is heightened and easily captured across multiple mediums, the impact of my research which explores not only the performance, but, importantly, the economic and ideological roots that shape and feed this performance, is increasingly relevant to understanding the contemporary Irish-American identity and relationship between Ireland and America.

With gratitude to my supervisor Dr. Barry Monahan and CACSSS for the generous funding. 